\title{
Stray seeds had antibiotic-resistance genes
}

Colin Macilwain, Washington

Hundreds of tonnes of genetically modified corn seeds sold to farmers by mistake over the past four years contained a gene for antibiotic resistance, Nature has learned. The release of such genes into the environment is sometimes considered inadvisable, as there is a small chance that they could flow from crops to microorganisms and spread problems of antibiotic resistance.

The Swiss biotechnology company Syngenta admitted last week that it had accidentally released a variety of corn (maize) called Bt 10 between 2001 and 2004. Like other crops with the name $B t$, this corn had been genetically modified to produce a protective pesticide. But $B t 10$ has not been approved for sale by regulatory agencies.

Officials at the company last week argued that $B t 10$ is basically identical to $B t 11$ corn, which has been approved for sale (see Nature 434, 423; 2005). But this week, Sarah Hull, a spokeswoman for Syngenta, confirmed that a marker gene that confers resistance to ampicillin, a commonly used antibiotic, was present in the $B t 10$ seeds. She adds that this gene would not have been active in the corn plants that grew from the seeds.

Antibiotic-resistance genes are widely used as 'tags' during the production of genetically modified crops, to help breeders identify and preserve desirable strains. But the genes are often removed before the seeds enter the food chain. The presence of the marker gene in Bt 10 corn was noted in a 2003 advice notice from a UK government committee, the Advisory Committee on Releases to the Environment, which was using $B t 10$ as a comparison to prove that

\section{IMAGE \\ UNAVAILABLE FOR COPYRIGHT REASONS}

Keeping track: antibiotic-resistance genes are often used as markers uring the production of transgenic crops such as $B t$ corn.

there were no marker genes in Bt 11 corn.

Critics have expressed surprise that neither Syngenta nor the US Environmental Protection Agency (EPA) announced the presence of the marker when they admitted that the release of $B t 10$ had taken place. "It is quite scandalous," says Greg Jaffe, head of the biotechnology project at the Center for Science in the Public Interest, a pressure group in Washington DC. "This shows that the government and the company are not being forthright."

Hull says that the company didn't mention the gene's presence because "it wasn't relevant to the health and safety discussion". She adds that the antibiotic-resistance genes have been around for a long time. “They've been studied extensively, and they pose no risk to humans or animals," she says. Regulators say that the genes present a very small risk to human health, either directly — if in the stomach of a patient on antibiotics, for example — or indirectly through gene flow into microbes.

Michael Rodemeyer, director of the Pew Initiative on Food and Biotechnology, a think-tank in Washington DC, says that the presence of such genes would be unlikely to see a crop declared unsafe in the United States — but adds that it could cause problems in Europe.

In a ruling published last April, for example, the European Food Safety Authority, which advises European Union governments on food issues, said that marker genes conferring resistance to ampicillin "should be restricted to field trials and not be present in genetically modified plants placed on the market". And the Codex Alimentarius Commission, the international food-standards body, has urged the agricultural biotechnology industry to use alternative methods to refine genetically modified strains in the future.

The EPA, which is jointly investigating the release of the Bt 10 corn with the US Department of Agriculture, declined to say what it knew about the antibiotic-resistance marker. "What the company told us and when about the marker gene is part of our ongoing investigation and we are not able to discuss it at this time," the agency said in a statement.

"I think they've done a terrible job," says Margaret Mellon, head of the food and environment programme at the Union of Concerned Scientists in Washington DC, referring to both Syngenta and the government agencies. "There are lots and lots of unanswered questions, and the longer they remain, the less confidence people are going to have in the technology and in the regulatory system."

\section{Deal paves way for Congress vote on stem-cell rules}

Erika Check, Washington

The US Congress looks set to vote on whether to loosen the restrictions that currently govern human embryonic stemcell research.

Under an agreement reached earlier this month, the Republican leadership of the House of Representatives will for the first time allow the body to debate and vote on whether to change the regulations.

The current rules, which were announced by President George W. Bush on 9 August 2001, prohibit the use of federal money to pay for research on human embryonic stem-cell lines created after that date. Congressman Mike Castle (Republican, Delaware), who favours easing the restrictions, says that he has reached a deal with Republican leaders Roy Blunt (Missouri), Eric Cantor (Virginia) and House speaker Dennis Hastert (Illinois). "My sense is that the speaker means to have a legitimate debate and a vote on whether to open up the policies on embryonic stem-cell research," Castle says.

Until now, the Republican leadership has opposed a review of Bush's rules. But developments since the policy was announced have convinced some prominent Republicans, including Senator Orrin Hatch (Utah), to reconsider. Scientists have said that there are not as many cell lines available as the president initially said there would be. And the lines have all been made or grown on animal cells, which means that they will not be suitable for clinical trials in people.

Castle claims that a $\mathbf{1 0 0}$ million people could benefit from the research. "I think the leadership understands the importance of that," Castle says, "and frankly some of them are probably in favour of it quietly, if not openly." 